\title{
Household Iodized Salt, Iodine Intake, and Thyroid Dysfunction in Reproductive Age Women in Different Regions of Iodine Adequacy
}

\author{
Suryati Kumorowulan, Yusi Dwi NurcahYANI and Leny LATIFAH \\ Health Research and Development Center, Magelang 56115, Indonesia
}

(Received June 27, 2019)

\begin{abstract}
Summary Iodine deficiency affects people of all age groups and yields detrimental health effects known as Iodine Deficiency Disorders (IDD). Universal Salt Iodization (USI) where above $90 \%$ household use iodized salt became the main program to optimized population iodine status. This study aimed to analyze iodine in salt, iodine status and thyroid functions from three different IDD endemic regions. Methods: This was a cross-sectional study, with women of reproductive age (15 to $45 \mathrm{y}$ old) as subjects, conducted in plain area (Yogyakarta) city ( $n=250)$, mountainous area (Bukit Tinggi city) $(n=249)$, and combination of mountaneous and plain area (Purworejo regency) $(n=249)$. Urinary iodine (UIE), prevalence of hyperthyroidism, and hypothyroidism (diagnostic based on combination of TSH and fT4 level), also the presence or absence and level of iodine in salt were assessed. Result: Iodized salt coverage have reached $>90 \%$ household in all three region, while titration found $75.6 \%$ with adequate level of iodine in salt $(>30 \mathrm{ppm})$, with wide range of iodine level in salt (0.00-218.2 ppm). With that condition, population in plain and combination of plain and mountainous area have more than adequate iodine status $(218 \mu \mathrm{g} / \mathrm{L}$ and $224 \mu \mathrm{g} / \mathrm{L}$ ), while population in mountaneous area still in mild iodine deficiency status (UIE median of $88 \mu \mathrm{g} / \mathrm{L}$ ). Most population is in euthyroid condition. Hyperthyroidism, subclinical hyperthyroidism, secondary hyperthyroidism, subclinical hypothyroidism, and hypothyroidism were found in $0.7 \%, 4.8 \%, 0.4 \%, 8.9 \%$, and $0.9 \%$ population consecutively. There were no relationship between iodine status and prevalence of hyperthyroidism and hypothyroidism, but subclinical hypothyroidism most prevalent in excess UIE population (12.5\% vs $8.3 \%$ ). Conclusion: All three regions have achieved USI target. But the risk of iodine deficiency still found in mountaneous area. Household iodized salt coverage discrepancy between rapid test and titration strengthen the need of more accurate but efficient test of iodine level in salt.
\end{abstract}

Key Words iodized salt, iodine intake, thyroid dysfunction, geographical risk

Iodine deficiency disorders are an iceberg phenomenon with the peak clinical manifestation is endemic cretinism. Since iodine plays important role in thyroid hormone synthesis, iodine deficiency can cause the thyroid may no longer be able to synthesize sufficient amounts of thyroid hormone. Sufficient quantities of thyroid hormones are needed for normal growth and development. Low level of thyroid hormones in the blood (hypothyroidism) is the principal factor responsible for harmful effects of health known collectively as "iodine deficiency disorders" (1). The spectrum of iodine deficiency disorders ranging from endemic goiter, hypothyroid, cretinism, and congenital abnormalities (2).

Initially, those included in the Iodine Deficiency Disorders (IDD) spectrum were limited to endemic goiter, endemic cretinism, and hypothyroidism. However, epidemiologically the IDD spectrum has wider and broader scope. Delange and Hetzel (3) stated that IDD affects humans at all stages of their life's development, from prenatal to elderly. IDD can cause miscarriage, disability, brain damage, decreased productivity and quality of

E-mail: suryatiyk@yahoo.co.id life. Furthermore, IDD-prone groups are including children, women of reproductive age, and pregnant women. IDD is a latent problem which can emerge at any time, thus monitoring and evaluation of IDD control must be implemented continuously.

Universal salt iodization (USI) and iodine fortification are effective strategies for preventing and controlling iodine deficiency (4). Salt iodization is the most effective intervention strategy for IDD prevention (5). USI with sufficient iodine salt is a sign of the success of the program in various countries with the goal of more than $90 \%$ of household coverage of iodized salt (1).

Nationally, the use of iodized salt in households at Indonesia based on Basic Health Research (Riskesdas) 2007 (6) and 2013 (7) were 62.3\% and 77.15\%, respectively. With iodine content that meet the recomendation $>30$ ppm are 23.4\% 6 and 43.2\% (7). Monitoring of iodized salt at the household level uses a qualitative method or rapid test with the criteria: iodine present or iodine absent. Meanwhile, measuring iodine levels at the manufacturing level are by using quantitative sampling with iodometric titration in the laboratory. Measurement of iodine levels in salt is one indicator of 
monitoring and evaluation of IDD at the community level.

IDD is a latent problem so it must always be monitored and evaluated. Mapping data of IDD in Indonesia was last carried out in 2003 (8). Since iodized salt is a major intervention for eliminating IDD worldwide, it is important to ensure that iodized salt meets the needs of vulnerable groups. Population living in mountaneous area is among vulnerable group impacted by IDD. Indonesia has begun salt iodization program since 1994. Our question is after $25 \mathrm{y}$ mandatory iodized salt, how is the accomplishment of USI target, iodine status, and thyroid function among population in different geographical risk of iodine adequacy.

This study aimed to investigate the iodine in salt, iodine status, and thyroid function among three different regions of iodine adequacy, which are mountaneous, plain, and combination of mountaneous and plain area.

\section{MATERIALS AND METHODS}

This was a preliminary study of developing tools for field quantitative salt measurement (9). This paper focus on analizing attainment of USI and relate it with the risk of deficient iodine intake and thyroid disfunction due to geographical risk. Method of this research was a cross sectional study with samples of women of reproductive age (15 to $45 \mathrm{y}$ old) in three location represented different geographical risk of iodine adequacy. First the city of Yogyakarta, an urban area located in plain land. Second, Purworejo regency, part of its area consisted of rural and also urban, part located in mountaneous and part of it plain area. The last is Bukit Tinggi city, semi urban area located in mountaneus area. This condition could affect the risk of iodine sufficiency and thyroid function.

Surveys were designed to provide representative information by sub-national domains (strata), determined according to their administrative or programmatic relevance. Probability proportional to size (PPS) methodology was used to select primary sampling units (PSUs) with systematic random selection of the required number of households within each PSU. Ethical approval was obtained from ethics comitee of NIHRD (National Institute of Health Research and Development). Written informed consent was obtained from subjects.

Blood and urine samples were collected from subjects signed informed consented. Non-fasting venous blood samples were drawn into vacutainers refrigerated immediately after collection, and transported to a central laboratory for processing the following morning. After centrifugation, serum and plasma samples were stored at $-20^{\circ} \mathrm{C}$ until analysis. Casual or spot urine samples were collected from subjects and transported to the Biochemical Laboratory of Research and Development Center Magelang located in Magelang Regency, Central Java.

We measured IDD indicator salt iodine level using a rapid test and titration. Indicators of iodine intake in population observed from urine iodine levels (UIE) using the spectrophotometry method. Iodine levels in urine describe daily iodine intake. This methods depend on iodide's role as a catalyst in the reduction of ceric ammonium sulfate (yellow colour) to the cerous form (colourless) in the presence of arsenious acid (the Sandell-Kolthoff reaction). Classification of iodine status in the population can be observed from the median urine iodine level $(4,10)$.

We also measured thyroid function by measuring TSH and Free T4 levels using the ELISA method. A combination of measurements of TSH and Free T4 used to determine whether thyroid function is hypothyroid, euthyroid or hyperthyroid. The reference values were FT4: 0.8-2.0 ng/dL, TSH: 0.3-4.0 mIU/L. The diagnostic criteria for thyroid diseases were as follows: overt hypothyroidism: TSH $>4.0 \mathrm{mIU} / \mathrm{L}$ and FT4 $<0.8 \mathrm{ng} /$ dL; subclinical hypothyroidism: TSH $>4.0 \mathrm{mIU} / \mathrm{L}, \mathrm{FT} 4$ within the reference range; overt hyperthyroidism: TSH $<0.3 \mathrm{mIU} / \mathrm{L}$ and FT4 >2.0 ng/dL; subclinical hyperthyroidism: TSH $<0.3 \mathrm{mIU} / \mathrm{L}$, Ft4 within the reference range; secondary hyperthyroidisme: FT4 >2.0 ng/dL, TSH within the reference range.

\section{RESULTS}

Table 1 shows that the mean age \pm standard deviation (SD) of women of reproductive ages was $34.8 \pm 8.30 \mathrm{y}$, and $49,4 \%$ were $36-44$ y old. Subjects in mix (combination of plain and mountainous) region were significantly in younger average than other regions $(p<0.05)$.

There are no significant difference in coverage of household iodised salt used rapid test and titration between regions. All region had more than 90\% coverage of household iodised salt used. When compared to measurements using titrations, the coverage of household iodised salt $>30 \mathrm{ppm}$ is only $75.5 \%$. Iodine status was adequate among women of reproductive ages from plain and mix (combination of plain and mountainous) region. Mountaneous area has lowest median UIE (88 $\mu \mathrm{g} / \mathrm{L})$ and stated as mild iodine deficiency area. There are significant difference on median UIE between groups. Iodine deficiency is still a public health issue in mountainous region, because proportion UIE $<50 \mu \mathrm{g} / \mathrm{L}$ is more than $20 \%$ and proportion UIE $<100 \mu \mathrm{g} / \mathrm{L}$ is more than $50 \%$ (1).

There is no difference in the prevalence of thyroid dysfunction between regions. Prevalence of hyperthyroidism and hypothyroidism was not difference between plain, mountainous, or mix (combination of plain and mountainous) region.

Table 2 shows there are no significant difference in coverage of household iodised salt used rapid test and titration between deficient, adequate, and excess group. Coverage of household iodised salt used $>90 \%$ in deficient, adequate, and excess iodine intake group. There is no significant relationship between thyroid dysfunction and UIE status. But, this study found higher prevalence of subclinical hypothyroidism in the excess groups than deficient and adequate groups $(12.5 \%$ vs $8.1 \%$ and $8.3 \%)$. 
Table 1. Household iodized salt, iodine intake, and thyroid dysfunction based on region $(n=748)$.

\begin{tabular}{|c|c|c|c|c|}
\hline Variable & $\begin{array}{c}\text { Plain } \\
(n=249)\end{array}$ & $\begin{array}{c}\text { Mix } \\
(n=249)\end{array}$ & $\begin{array}{l}\text { Mountainous } \\
\quad(n=250)\end{array}$ & $\begin{array}{c}\text { Total } \\
(n=748)\end{array}$ \\
\hline Years of age & $36.0 \pm 8.73$ & $33.7 \pm 8.50$ & $34.8 \pm 7.64$ & $34.8 \pm 8.30$ \\
\hline \multicolumn{5}{|l|}{ Age categories ${ }^{\text {a }}$} \\
\hline$<25$ y & $13.9(28)$ & $15.6(31)$ & $12.3(30)$ & $13.8(89)$ \\
\hline $25-35 y$ & $22.4(45)$ & $31.7(63)$ & $28.3(69)$ & $27.5(177)$ \\
\hline $36-44 y$ & $47.3(95)$ & $48.2(96)$ & $52.5(128)$ & $49.6(319)$ \\
\hline$\geq 45 \mathrm{y}$ & $16.4(33)$ & $4.5(9)$ & $7.0(17)$ & $9.2(59)$ \\
\hline \multicolumn{5}{|l|}{ Household iodised salt used status ${ }^{\mathrm{a}, \mathrm{b}, \mathrm{s}}$} \\
\hline Yes & $96.4(240)$ & $90.1(200)$ & $92.9(210)$ & $93.3(650)$ \\
\hline $\begin{array}{l}\text { Household iodised salt level (titration), } \\
\mathrm{ppm}^{\#}\end{array}$ & $39.4(0.0-218.2)$ & $35.7(0.8-175.2)$ & $41.2(0.0-184.4)$ & $39.4(0.0-218.2)$ \\
\hline \multicolumn{5}{|l|}{ Salt titration category ${ }^{\mathrm{b}, \#}$} \\
\hline$\geq 30 \mathrm{ppm}$ & $80.3(179)$ & $67.6(152)$ & $78.7(174)$ & $75.5(505)$ \\
\hline \multicolumn{5}{|l|}{ Iodine adequacy status ${ }^{\mathrm{b}}$} \\
\hline - Inadequate $(<50 \mu \mathrm{g} / \mathrm{mL})$ & $3.2(8)$ & $1.2(3)$ & $25.2(63)$ & $9.9(74)$ \\
\hline - Deficiency (50-99 $\mu \mathrm{g} / \mathrm{mL})$ & $6.8(17)$ & $11.2(28)$ & $32.4(81)$ & $16.9(126)$ \\
\hline - Sufficient (100-199 $\mu \mathrm{g} / \mathrm{mL})$ & $32.5(82)$ & $30.9(77)$ & $29.7(74)$ & $31.0(232)$ \\
\hline - more than adequate $(200-299 \mu \mathrm{g} / \mathrm{mL})$ & $34.9(87)$ & $28.9(72)$ & $11.2(28)$ & $25.1(187)$ \\
\hline - Iodine excessive (100-199 $\mu \mathrm{g} / \mathrm{mL})$ & $22.1(55)$ & $27.7(69)$ & $1.6(4)$ & $17.1(128)$ \\
\hline $\mathrm{TSH}, \mathrm{mIU} / \mathrm{mL}^{\#}$ & $1.72(0.01-15.07)$ & $1.44(0.03-9.54)$ & $1.88(0.01-31.05)$ & $1.69(0.01-31.05)$ \\
\hline \multicolumn{5}{|l|}{ TSH status ${ }^{b}$} \\
\hline - below normal (>4.0 mIU/mL) & $12.0(30)$ & $7.6(19)$ & $10.0(25)$ & $9.9(74)$ \\
\hline - above normal (<0.3 mIU/mL) & $6.4(16)$ & $5.6(14)$ & $4.8(12)$ & $5.6(42)$ \\
\hline Free $\mathrm{T} 4, \mathrm{ng} / \mathrm{L}^{\#}$ & $1.15(0.63-3.34)$ & $1.35(0.78-2.09)$ & $1.22(0.10-2.91)$ & $1.25(0.10-3.34)$ \\
\hline \multicolumn{5}{|l|}{ fT4 status ${ }^{\mathrm{b}, \$}$} \\
\hline - below normal (<0.8 ng/L) & $2.4(6)$ & $0.8(2)$ & $4.8(12)$ & $2.7(20)$ \\
\hline - above normal (<0.3 mIU/mL) & $0.8(2)$ & $0.4(1)$ & $2.0(5)$ & $1.1(8)$ \\
\hline \multicolumn{5}{|l|}{ Diagnostic of thyroid function ${ }^{b}$} \\
\hline - Hyperthyroidism & $0.4(1)$ & $0.4(1)$ & $1.6(4)$ & $0.7(5)$ \\
\hline - Subclinical hyperthyroidism & $5.6(14)$ & $5.6(14)$ & $3.2(8)$ & $4.8(36)$ \\
\hline - Secondary hyperthyroidism & $0.4(1)$ & $0.4(1)$ & $0.4(1)$ & $0.3(2)$ \\
\hline - Subclinical hypothyroidism & $10.8(27)$ & $7.6(19)$ & $8.4(21)$ & $9.0(67)$ \\
\hline - Hypothyroidism & $1.2(3)$ & $0.0(0)$ & $1.6(4)$ & $0.9(7)$ \\
\hline
\end{tabular}

\# Data are presented as median (min-max), Kruskal-Wallis one-way analysis of variance, there are a significant difference between groups $(p<0.005)$.

$\$$ Chi-square analysis, there are a significant difference between groups $(p<0.05)$.

${ }^{a}$ Value are presented in \% and numbers of participans in parantheses, $\%(n)$.

${ }^{\mathrm{b}}$ Coverage of household iodised salt used status was assessed using rapid iodised salt test method.

\section{DISCUSSION}

This study found that population in mountaneous area were still in the risk of iodine deficiency with median UIE at $88 \mu \mathrm{g} / \mathrm{L}$, while two other regions have achieved more than adequate iodine intake status $(218 \mu \mathrm{g} / \mathrm{L}$ and $224 \mu \mathrm{g} / \mathrm{L})$. Iodine level in salt was test with a rapid test and titration. Rapid test showed 95,97\% households in plain area, 93.07\% in combination of plain and mountaneous area, and 93\% in mountaneous area used iodized salt. It indicated that Universal Salt Iodization (USI). Globally the iodized salt program for all (USI) is believed to be able to overcome thyroid disfunction due to iodine deficiency $(11,12)$.

Results of this study indicated, populations in the plain area and combinations of plain and mountaineous area were already in more than adequate iodine status, while mountainous area is still in the status of mild iodine deficiency.

In accordance with this research, a research in Haiti, which compared adequacy of iodine status in coastal, urban and mountainous populations found, while coastal and urban areas have reached non-endemic iodine status, mountainous area still in mild endemic iodine deficiency status (13). Study in Iran comparing pregnant women living in plain versus mountainous area also confirmed the higher prevalence of iodine deficiency in pregnant women living in mountainous area (14), same result were also found in Tibetan adult, which had higher prevalent of IDD compare with population living in plains China (15). The distribution of IDD reflects the geochemistry of iodine. IDD governed by the external supply of iodine from the marine environment via the atmosphere. Beside external supply, 
Table 2. Household iodised salt, iodine status, and thyroid dysfunction based on UIE status.

\begin{tabular}{|c|c|c|c|c|}
\hline Variable & $\begin{array}{l}\mathrm{UIE}<100 \mu \mathrm{g} / \mathrm{L} \\
\quad(n=200)\end{array}$ & $\begin{array}{c}\text { UIE } 100-299 \mu \mathrm{g} / \mathrm{L} \\
(\mathrm{n}=420)\end{array}$ & $\begin{array}{l}\mathrm{UIE} \geq 300 \mu \mathrm{g} / \mathrm{L} \\
\quad(n=128)\end{array}$ & $\begin{array}{c}\text { Total } \\
(n=748)\end{array}$ \\
\hline Years of age & $35.3 \pm 7.67$ & $34.5 \pm 8.56$ & $35.2 \pm 8.45$ & $34.8 \pm 8.30$ \\
\hline \multicolumn{5}{|l|}{ Age categories ${ }^{\mathrm{a}}$} \\
\hline$<25 \mathrm{y}$ & $10.4(19)$ & $15.4(56)$ & $13.5(14)$ & $13.8(89)$ \\
\hline $25-35 y$ & $27.5(50)$ & $27.7(99)$ & $26.9(28)$ & $27.5(177)$ \\
\hline $36-44 y$ & $52.796)$ & $47.1168)$ & $52.9(55)$ & $49.6(319)$ \\
\hline$\geq 45 \mathrm{y}$ & $9.3(17)$ & $9.8(35)$ & $6.7(7)$ & $9.2(59)$ \\
\hline \multicolumn{5}{|l|}{ Household iodised salt used status ${ }^{\mathrm{c}}$} \\
\hline Yes & $92.4(171)$ & $93.9(370)$ & $92.4(110)$ & $93.3(651)$ \\
\hline $\begin{array}{l}\text { Household iodised salt level (titration). } \\
\text { ppm }\end{array}$ & $39.4(0.0-179.1)$ & $39.4(0.0-218.2)$ & $38.6(3.6-175.2)$ & $39.4(0.0-218.2)$ \\
\hline \multicolumn{5}{|l|}{ Salt titration category ${ }^{\mathrm{d}}$} \\
\hline$<30 \mathrm{ppm}$ & $27.5(49)$ & $22.0(83)$ & $28.1(32)$ & $24.5(164)$ \\
\hline$\geq 30 \mathrm{ppm}$ & $72.5(129)$ & $78.2(294)$ & $71.9(82)$ & $75.6(505)$ \\
\hline $\mathrm{TSH}, \mathrm{mIU} / \mathrm{mL}$ & $1.78(0.04-15.42)$ & $1.63(0.01-31.05)$ & $1.48(0.04-9.44)$ & $1.69(0.01-31.05)$ \\
\hline \multicolumn{5}{|c|}{ 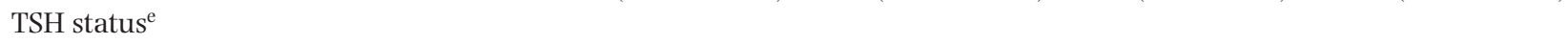 } \\
\hline - below normal (>4.0 mIU/mL) & $10.5(21)$ & $8.6(36)$ & $13.3(17)$ & $9.9(74)$ \\
\hline - above normal (<0.3 mIU/mL) & $3.5(7)$ & $6.7(28)$ & $5.5(7)$ & $5.6(42)$ \\
\hline Free $\mathrm{T} 4, \mathrm{ng} / \mathrm{L}^{\#}$ & $1.20(0.33-2.77)$ & $1.27(0.10-3.34)$ & $1.21(0.63-2.09)$ & $1.24(0.10-3.34)$ \\
\hline \multicolumn{5}{|l|}{ fT4 status ${ }^{\mathrm{e}}$} \\
\hline - below normal $(<0.8 \mathrm{ng} / \mathrm{L})$ & $4.5(9)$ & $1.4(6)$ & $3.9(5)$ & $2.7(20)$ \\
\hline - above normal (<0.3 mIU/mL) & $0.5(1)$ & $1.4(6)$ & $0.8(1)$ & $1.1(8)$ \\
\hline \multicolumn{5}{|l|}{ Diagnostic of thyroid function ${ }^{\mathrm{e}}$} \\
\hline - Hyperthyroidism & $0.5(1)$ & $1.0(4)$ & $0.0(0)$ & $0.7(5)$ \\
\hline - Subclinical hyperthyroidism & $3.0(6)$ & $5.7(24)$ & $4.7(6)$ & $4.8(36)$ \\
\hline - Secondary hyperthyroidism & $0.0(0)$ & $0.5(2)$ & $0.8(1)$ & $0.4(3)$ \\
\hline - Subclinical hypothyroidism & $8.5(17)$ & $8.1(34)$ & $12.5(16)$ & $8.9(67)$ \\
\hline - Hypothyroidism & $2.0(4)$ & $0.5(2)$ & $0.8(1)$ & $0.9(7)$ \\
\hline
\end{tabular}

${ }^{\$}$ Data are presented as mean \pm SD, ANOVA analysis, there are a significant difference between groups $(p<0.1)$.

\#Data are presented as median (min-max), Kruskal-Wallis analysis, there are a significant difference between groups $(p<0.05)$.

${ }^{\mathrm{a}}$ Value are presented in \% and numbers of participans in parantheses, \% ( $n$ ). UIE $<100 \mu \mathrm{g} / \mathrm{L} n=182$, UIE $100-299 \mu \mathrm{g} / \mathrm{L}$ $n=358$, UIE $\geq 300 \mu \mathrm{g} / \mathrm{L} n=104$.

${ }^{\mathrm{b}}$ Value are presented in \% and numbers of participans in parantheses, \% (n). UIE <100 $\mu \mathrm{g} / \mathrm{L} n=193$, UIE 100-299 $\mu \mathrm{g} / \mathrm{L}$ $n=393$, UIE $\geq 300 \mu \mathrm{g} / \mathrm{L} n=116$.

${ }^{\mathrm{c}}$ Value are presented in \% and numbers of participans in parantheses, \% (n). UIE $<100 \mu \mathrm{g} / \mathrm{L} n=185$, UIE $100-299 \mu \mathrm{g} / \mathrm{L}$ $n=394$, UIE $\geq 300 \mu \mathrm{g} / \mathrm{L} n=119$, coverage of household iodised salt used status was assessed using rapid iodised salt test method.

${ }^{\mathrm{d}}$ Value are presented in \% and numbers of participans in parantheses, \% (n). UIE $<100 \mu \mathrm{g} / \mathrm{L} n=178$, UIE $100-299 \mu \mathrm{g} / \mathrm{L}$ $n=377$, UIE $\geq 300 \mu \mathrm{g} / \mathrm{L} n=114$.

${ }^{\mathrm{e}}$ Value are presented in \% and numbers of participans in parantheses, \% (n).

bioavailability of iodine in soils and water also became important factors (16). This could explain the higher prevalence of IDD in mountainous regions. Higher level of rainfall and flooding, soil erosion, exacerbated by overfarming and lack of access to seafood sources of iodine could heightened the risk of IDD (17).

Research in mountainous area of Artsakh in Nogorno Karabach became a success story of IDD elimination in mountainous area. The open access to food sources from other places, because Artsakh imports food, including iodized salt from Armenia which has implemented mandatory salt iodization, was able to provide enough iodine but not excessive to Artsakh population (18).

Regarding to household coverage of iodized salt, this research found, more than $90 \%$ subjects had accessed iodized salt. But further analysis showed a high variety of iodine level in salt (0-218.2 ppm). In order to supply $150 \mu \mathrm{g} / \mathrm{d}$ iodine through salt, the concentration at the production site should be within the range of $20-40 \mathrm{mg}$ of iodine $/ \mathrm{kg}$ of salt (20-40 ppm, equivalent to 34-66 $\mathrm{mg}$ of potassium iodate/kg of salt) (19). Research on reproductive age women in Bener Purworejo found estimation of salt daily intake was $7.3 \pm 2.1 \mathrm{~g}$ per person/d. Indonesia uses potassium iodat, with $30 \mathrm{ppm}$ as the recommended (20). Eventhough result of the rapid test showed accomplishment of USI, when it came to quality of the salt, the result showed $75.6 \%$ household iodized salt $>30$ ppm, which show $17.7 \%$ discrepancy. The high variation of iodine level in household iodized salt also found in other countries, with population in rural and lower socioeconomic status in greater risk of 
difficulty accessing iodized salt with adequate level (2123). The problem of accurate detection of iodine level in salt was also found. Epidemiological surveillance tend to use rapid test to determine iodine in salt qualitatively. The titration is unfeasible to use in many occasion of field research. Result of this study strengthen the need of more accurate but economic and efficient test of iodine level in salt, especially in field surveillance.

Iodine intake should be modest and appropriate. Deficiency and also excess intake of iodine could lead to the higher risk of thyroid dysfunction. Thyroid functions can be classified into 3 groups namely hypothyroid, hyperthyroid or euthyroid (normal) $(5,19,24)$. In this study, subclinical hypothyroidism cases was higher in the excess UIE (12.5\%), but not significantly different than other UIE groups. This result in accordance with research on estimating the difference regarding UIE between cases of hypothyroidism and controls with the aim of generating evidence for recommendations regarding USI. Patient with hypothyroidism had high odds exposure to UIE excess (25). Another study reported that higher median UIE was found in subclinical hypothyroidism case $(224.9 \mu \mathrm{g} / \mathrm{L})$ than controls (189.9 $\mu \mathrm{g} / \mathrm{L})(26)$. The relationship between iodine intake and thyroid disorders in populations is U-shaped: both deficient and excessive iodine intakes may impair thyroid function (27). The study that examined iodine status and thyroid function in China found that the TSH value decreased and subsequently increased with the elevation of UI and formed a "U curve" relationship in children, adults and pregnant women. Subclinical hypothyroidism was likely to occur more easily in the populations with iodine intakes above and below the reference range (28). Researches found high iodine intake tends to cause thyroid disease through long-term mechanisms. Hence, assessment of individual UIE recommended, due to instability of iodine nutritional status $(25,26)$.

\section{CONCLUSION}

Iodized salt coverage have reached $>90 \%$ household in all three regions with different geographical risk of iodine deficiency (93.3\%). With the same accomplishment of USI, population representing mountainous regions still in mild iodine deficiency (UIE median of $88 \mu \mathrm{g} / \mathrm{L})$. Population representing plain and combination of plain and mountainous regions have achieved more than adequate level of iodine intake. Titration test showed $75.6 \%$ household salt with iodine level $>30$ ppm.

Majority of population in three regions is on euthyroid state, and no different prevalence of hypothyroid or hyperthyroidism found between regions.. Subclinical hypothyroidism cases was higher in excess iodine intake population (12.5\% vs $8.3 \%$ ), but not significantly different than other UIE groups.

\footnotetext{
Disclosure of state of COI

No conflicts of interest to be declared.
}

\section{Acknowledgments}

We would like to show a gratitude to the head and staffs of Yogyakarta city health office, Purworejo regency health office, Bukit Tinggi city health office for their assistance and cooperation in this research.

\section{REFERENCES}

1) World Health Organization. 2007. Assessment of Iodium Deficiency Disorders and Monitoring Their Elimination: A Guide For Programme Managers. 3rd ed. WHO, Geneva.

2) Hess SY, Zimmermann MB, Adou P, Torresani T, Hurrell RF. 2002. Treatment of iron deficiency in goitrous children improves the efficacy of iodized salt in Côte d'Ivoire. Am J Clin Nutr 75: 743-748.

3) Delange F, Hetzel BS. 2004. The Scientific Basis for the Elimination of Brain Damage Due to Iodium Deficiency. In: Towards the Global Elimination of Brain Damage Due to Iodium Deficiency: A global program for human development with a model applicable to a variety of health, social and environmental problems (Hetzel BS, ed). New York: Oxford University Press.

4) Andersson M, de Benoist B, Rogers L. 2010. Epidemiology of iodine deficiency: Salt iodisation and iodine status. Best Pract Res Clin Endocrinol Metab 24: 1-11.

5) Zimmerman MB. 2008. Iodine Requirements and the Risks and Benefits of Correcting Iodine Deficiency in Populations. J Trace Elem Med Biol 22: 81-92.

6) Center of Research and Development of Nutrition and Food/United Nations Children's Fund (Unicef). 2008. Survey of indicators of iodine deficiency disorders. Basic health research (Riskesdas). Final report. Center of Research and Development of Nutrition and Food, Bogor (In Bahasa Indonesia).

7) Ministry of Health Republic Indonesia. 2013. The main result of Riskesdas Indonesia 2013. National report. Research report. National Institute of Health Research and Development, Jakarta (In Bahasa Indonesia).

8) Ministry of Health, Directorate General of Community Health Directorate of Community Nutrition. 2003. Technical Assistance for Evaluation on Intensified Iodium Deficiency Control Project. IBRD LOAN No.4125-Ind.

9) Kumorowulan S. 2017. Development of quantitative salt measurement methods in area with varying degrees of iodine adequacy. Final report. Magelang Health Research and Development Center, Magelang (In Bahasa Indonesia).

10) Zimmermann MB, Boelaert K. 2015. Iodine deficiency and thyroid disorders. Lancet Diabetes Endocrinol 3(4): 286-295.

11) Andersson M, Karumbunathan V, Zimmermann MB. 2012. Global iodine status in 2011 and trends over past decade. J Nutr 142(4): 744-750.

12) Zimmermann MB, Aeberli I, Andersson M, Assey V, Yorg JAJ, Jooste P, et al. 2013. Thyroglobulin is A sensitive measure of both deficienct and excess iodine intake in children and indicates no adverse effects of thyroid function in UIC range of 100-299 mg/L: A UNICEF/ ICCIDD study group report, J Clin Endocrinol Metab 98(3): 1271-1280.

13) Von Oettingen JE, Brathwaite TD, Carpenter C, Bonnell R, He X, Braverman LE, et al. 2017. Population survey of iodine deficiency and environmental disruptors of thyroid function in Young Children in Haiti. J Clin Endo- 
crinol Metab 102(2): 644-651.

14) Rostami R, Beiranvend A, Nourooz-Zadeh J. 2012. Nutritional iodine status in gestation and its relation to geographic features in Urmia County of northwest Iran. Food Nutr Bull 33(4): 267-272.

15) Ning $P$, Ren $Q$, Teng D, Zhang Z, Lu X, Meng S, et al. 2020. Current iodine nutrition status and prevalence of thyroid disorders in Tibetan adults in an oxygen-deficient plateau, Tibet, China: A population-based study. Thyroid 30: 759-766.

16) Fuge R. Soils and iodine deficiency. 2005. In: Essentials of medical geology. Impacts of natural environment on public health (Selinus O, Ed). Elseiver academic press, USA.

17) Kotwal A, Kotwal J, Prakash R, Kotwal N. 2015. Does iodine excess lead to hypothyroidism? Evidence from a case-control study in India. Arch Med Res 46: 490-494.

18) Sebotsa MLD, Dannhauser A, Jooste PL, Joubert G. 2005. Iodine status as determined by urinary iodine excretion in Lesotho two years after introducing legislation on universal salt iodization. Nutrition 21(1): 2024.

19) Hutchings N, Baghdasaryan S, Qefoyan M, Chiloyan A, Manoukian M, Atayan K, et al. 2018. Iodine nutrition in the Republic of Artsakh (Nagorno Karabakh). Endocr Pract 24(5): 468-472.

20) Zimmermann MB. 2009. Iodine Deficiency. Endocr Rev 30(4): 376-408.

21) Nurcahyani YD, Ihsan N, Kumorowulan S. 2016. Alteration of UIE, TSH, and Free T4 Level in Childbearing
Age Women After Intervention of 30-35 ppm KIO3 Iodized Salt. MGMI 7(2): 77-90.

22) Tran TD, Hetzel B, Fisher J. 2016. Access to iodized salt in 11 low- and lower-middle-income countries: 2000 and 2010. Bull World Health Organ 94(2): 122-129.

23) Zahidi A, Zahidi M, Taoufik J. 2016. Assessment of iodine concentration in dietary salt at household level in Morocco. BMC Public Health 16: 418.

24) Universal Salt Iodization Coverage Survey Team. 2017. Household coverage with adequately iodized salt varies greatly between countries and by residence type and socioeconomic status within countries: Results from 10 national coverage surveys. J Nutr 147(5): 1004S1014 S.

25) Zimmermann MB, Jooste PL, Pandav CS. 2008. Iodine deficiency disorders. Lancet 372: 1251-1262.

26) Kotwal A, Kotwal J, Prakash R, Kotwal N. 2015. Does iodine excess lead to hypothyroidism? Evidence from a case-control study in India. Arch Med Res 46: 490-494.

27) Shrestha U, Gautam N, Agrawal KK, Jha AC, Jayan A. 2017. Iodine status among subclinical and overt hypothyroid patients by urinary iodine assay: A case-control study. Indian J Endocrinol Metab 21(5): 719-723.

28) Zimmermann MB. 2019. Iodine Deficiency. In: The Thyroid and Its Diseases (Luster M, Duntas L, Wartofsky L, eds). Springer, Cham.

29) Meng F, Zhao R, Liu P, Liu L, Liu S. 2013. Assessment of iodine status in children, adults, pregnant women and lactating women in iodine-replete areas of China. PLoS One 8(11): e81294. 